\author{
N.T. Orumbayeva, A.B. Keldibekova \\ Ye.A. Buketov Karaganda State University, Kazakhstan \\ (E-mail: OrumbayevaN@mail.ru)
}

\title{
On the solvability of the duo-periodic problem for the hyperbolic equation system with a mixed derivative
}

\begin{abstract}
One of the main and most studied problems in the theory of second order hyperbolic equations is a periodic boundary value problem. To solve such problems apply Fourier method, method of successive approximations, methods of functional analysis, variational method, etc. The development of information technologies imposes new requirements on the developed methods, paying special attention to their constructibility. One of such constructive methods is the method of a parametrization proposed in the works of D. S.Dzhumabaev for solving two-point boundary-value problems for ordinary differential equations. In this paper, we consider a boundary value problem for both variables for a system of hyperbolic equations with a mixed derivative. To solve this problem, the notation is introduced and the periodic boundary value problem is reduced to an equivalent problem consisting of a family of periodic boundary value problems for an ordinary differential equation and an integral relation. To solve the problem obtained, the method of a parametrization is used. The application of this method allowed us to construct an algorithm for finding an approximate solution of the periodic boundary value problem for a system of hyperbolic equations with a mixed derivative. In addition, the coefficient conditions of convergence and feasibility of the proposed algorithm are obtained.
\end{abstract}

Keywords: the duo-periodic boundary value problem, the method of a parametrization, the hyperbolic equation system, mixed derivatives.

\section{Introduction}

One of the main and most studied problems of the theory of the hyperbolic equations of the second order is a periodic boundary value problem. A systematic study of periodic boundary value problems for hyperbolic equations with mixed partial derivatives started in 60s with the work of L. Cesari [1]. J.K. Hale [2], G. Hecquet [3], A.K. Aziz [4], V. Lakshmikantham [5], S.V. Zhestkov, A.M. Samoylenko, T.I. Kiguradze, B.I. Ptashnik, Yu.A. Mitropolskiy, G.P. Homa, M.I. Gromyak and others dealt with further investigations of the solvability of periodic boundary value problems. To solve periodic boundary value problems of second order hyperbolic equations, were applied the Fourier method, the method of successive approximations, the methods of functional analysis, the variational method, etc. Despite the presence of numerous methods for study of periodic boundary value problems, interest in them continues to this day. The application of different approaches, ideas and methods leads to results formulated in different terms. The development of information technologies and its comprehensive application in applied problems imposes new requirements of the developed methods. Particular attention got to be paid to the methods that are different from others in their constructiveness at the stage of approximate construction of solutions and in the study of such qualitative issues as the establishment of the existence of a solution, the rationale for the convergence of approximate solutions to the exact one, an estimate of the inaccuracy of the approximate solution.

One of such constructive methods is the method of a parametrization [6, 7], proposed for solving two-point boundary value problems of ordinary differential equations. The point of using this method is to enter additional parameters and bring the original problem to multipoint boundary value problem with a parameter. It allows in terms of initial data to set conditions for the solvability of the boundary value problem for ordinary differential equations and to propose a family of algorithms for finding its approximate solution.

A modification of the method of a parametrization is the method of introducing functional parameters, devised in the works [8-16], which finds its application in the study of nonlocal boundary value problems with data on characteristics for a system of hyperbolic equations with a mixed derivative with two independent 
variables. There were constructed two-parameter families of algorithms for finding solutions to nonlocal boundaryvalue problems, at each step of which the Goursat problems are solved. On the basis of this algorithm was established the solvability of the boundary value problem with data on the characteristics for the system of hyperbolic equations with mixed derivative. However, the problems related to solvability of duo-periodic boundary value problems for the system of hyperbolic equations with mixed derivative remain relevant.

Problem statement. On $\Omega=[0, \omega] \times[0, T]$ we consider a duo-periodic problem for a system of hyperbolic equations of the form

$$
\begin{gathered}
\frac{\partial^{2} z}{\partial x \partial t}=A(x, t) \frac{\partial z}{\partial x}+z+f(x, t), \quad(x, t) \in \Omega \\
z(0, t)=z(\omega, t), \quad t \in[0, T] ; \\
z(x, 0)=z(x, T), \quad x \in[0, \omega],
\end{gathered}
$$

where $(n \times n)$ - matrix $A(x, t) ; n$ - vector-function $f(x, t)$ are continuous by $\Omega,\|z(x, t)\|=\max _{i=1, n}\left|z_{i}(x, t)\right|$; $\|A(x, t)\|=\max _{i=1, n} \sum_{j=1}^{n}\left|a_{i j}(x, t)\right|$. Let $C\left(\Omega, R^{n}\right)$ - be the space of functions $z: \Omega \rightarrow R^{n}$ continuous on $\Omega$, with norm $\|z\|_{0}=\frac{\max }{(x, t) \in \Omega}\|z(x, t)\|$. Function $z(x, t) \in C\left(\Omega, R^{n}\right)$ having partial derivatives $\frac{\partial z(x, t)}{\partial x} \in C\left(\Omega, R^{n}\right)$, $\frac{\partial^{2} z(x, t)}{\partial x \partial t} \in C\left(\Omega, R^{n}\right)$ is called the solution of the problem $(1)-(3)$, if it satisfies the system $(1)$ for all $(x, t) \in \Omega$ and periodic conditions (2), (3).

We consider a periodic boundary value problem with one independent variable to find solution of this problem

$$
\begin{gathered}
\frac{\partial^{2} u}{\partial x \partial t}=A(x, t) \frac{\partial u}{\partial x}+u+f(x, t), \quad(x, t) \in \Omega \\
u(0, t)=0, \quad t \in[0, T] \\
u(x, 0)=u(x, T), \quad x \in[0, \omega] .
\end{gathered}
$$

We enter new unknown function $v(x, t)=\frac{\partial u(x, t)}{\partial x}$ and reduce the periodic boundary value problem for a system of hyperbolic equations to a family of periodic boundary value problems for ordinary differential equations and a functional relation. Next, we apply the method of a parametrization [7]. By step $h>0: N h=T$ we produce a partition of $[0, T)=\bigcup_{r=1}^{N}[(r-1) h, r h), \quad N=1,2, \ldots$. The region $\Omega$ is divided into $N$ parts. By using $v_{r}(x, t), u_{r}(x, t)$ denote respectively the restriction of the function $v(x, t), u(x, t)$ on $\Omega_{r}=[0, \omega] \times$ $[(r-1) h, r h), r=\overline{1, N}$.

Then problem (4)-(6) be equivalent to the boundary value problem

$$
\begin{gathered}
\frac{\partial v_{r}}{\partial t}=A(x, t) v_{r}+u_{r}(x, t)+f(x, t), \quad(x, t) \in \Omega_{r} \\
v_{1}(x, 0)-\lim _{t \rightarrow T-0} v_{N}(x, t)=0, \quad x \in[0, \omega] \\
\lim _{t \rightarrow s h-0} v_{s}(x, t)=v_{s+1}(x, s h), \quad s=\overline{1, N-1} ; \\
u_{r}(x, t)=\int_{0}^{x} v_{r}(\xi, t) d \xi, \quad(x, t) \in \Omega_{r}, \quad r=\overline{1, N}
\end{gathered}
$$

where $(7)$ - is the condition of gluing the functions $v(x, t)$ in the inner split lines. In $\lambda_{r}(x)$ we denote the value of $v_{r}(x, t)$ when $t=(r-1) h$, i.e $\lambda_{r}(x)=v_{r}(x,(r-1) h)$ and will replace

$$
\tilde{v}_{r}(x, t)=v_{r}(x, t)-\lambda_{r}(x), \quad r=\overline{1, N} .
$$

We obtain an equivalent boundary value problem with unknown functions $\lambda_{r}(x)$ :

$$
\begin{gathered}
\frac{\partial \tilde{v}_{r}}{\partial t}=A(x, t) \tilde{v}_{r}+A(x, t) \lambda_{r}(x)+u_{r}(x, t)+f(x, t), \quad(x, t) \in \Omega_{r} \\
\tilde{v}_{r}(x,(r-1) h)=0, \quad x \in[0, \omega], \quad r=\overline{1, N}
\end{gathered}
$$




$$
\begin{gathered}
\lambda_{1}(x)-\lambda_{N}(x)-\lim _{t \rightarrow T-0} \tilde{v}_{N}(x, t)=0, \quad x \in[0, \omega] \\
\lambda_{s}(x)+\lim _{t \rightarrow s h-0} \tilde{v}_{s}(x, t)-\lambda_{s+1}(x)=0, x \in[0, \omega], s=\overline{1, N-1} \\
u_{r}(x, t)=\int_{0}^{x} \tilde{v}_{r}(\xi, t) d \xi+\int_{0}^{x} \lambda_{r}(\xi) d \xi,(x, t) \in \Omega_{r}, r=\overline{1, N} .
\end{gathered}
$$

The problem (8), (9) for fixed $\lambda_{r}(x), u_{r}(x, t)$ is a single-parameter family of Cauchy problems for systems of ordinary differential equations, where $x \in[0, \omega]$ and is equal to the integral equation

$$
\begin{gathered}
\tilde{v}_{r}(x, t)=\int_{(r-1) h}^{t} A(x, \tau) \tilde{v}_{r}(x, \tau) d \tau+ \\
+\int_{(r-1) h}^{t} A(x, \tau) d \tau \cdot \lambda_{r}(x)+\int_{(r-1) h}^{t}\left[u_{r}(x, \tau)+f(x, \tau)\right] d \tau .
\end{gathered}
$$

Instead of $\tilde{v}_{r}(x, t)$ substitute the appropriate right part $(13)$ and by repeating this process $\nu(\nu=1,2, \ldots)$ times we will get

$$
\tilde{v}_{r}(x, t)=D_{v r}(x, t) \lambda_{r}(x)+F_{v r}\left(x, t, u_{r}\right)+G_{v r}\left(x, t, \tilde{v}_{r}\right), r=\overline{1, N},
$$

where

$$
\begin{gathered}
D_{\nu r}(x, t)=\sum_{j=0}^{\nu-1} \int_{(r-1) h}^{t} A\left(x, \tau_{1}\right) \ldots \int_{(r-1) h}^{\tau_{j}} A\left(x, \tau_{j+1}\right) d \tau_{j+1} \ldots d \tau_{1} ; \\
F_{v r}\left(x, t, u_{r}\right)=\int_{(r-1) h}^{t}\left[u_{r}\left(x, \tau_{1}\right)+f\left(x, \tau_{1}\right)\right] d \tau_{1}+\sum_{j=1}^{v-1} \int_{(r-1) h}^{t} A\left(x, \tau_{1}\right) \ldots \\
\ldots \int_{(r-1) h}^{\tau_{j-1}} A\left(x, \tau_{j}\right) \int_{(r-1) h}^{\tau_{j}}\left[u_{r}\left(x, \tau_{j+1}\right)+f\left(x, \tau_{j+1}\right)\right] d \tau_{j+1} d \tau_{j} \ldots d \tau_{1} ; \\
G_{v r}\left(x, t, \tilde{v}_{r}\right)=\int_{(r-1) h}^{t} A\left(x, \tau_{1}\right) \ldots \int_{(r-1) h}^{\tau_{v-2}} A\left(x, \tau_{v-1}\right) \int_{(r-1) h}^{\tau_{v-1}} A\left(x, \tau_{v}\right) \tilde{v}_{r}\left(x, \tau_{v}\right) d \tau_{v} d \tau_{v-1} \ldots d \tau_{1},
\end{gathered}
$$

$\tau_{0}=t, r=\overline{1, N}$. Moving to the limit at $t \rightarrow r h-0$, in (14) we find $\lim _{t \rightarrow r h-0}=\tilde{v}_{r}(x, t), r=\overline{1, N}$, for unknown functions $\lambda_{r}(x), r=\overline{1, N}$, we obtain a system of functional equations:

$$
Q_{\nu}(x, h) \lambda(x)=-F_{\nu}(x, h, u)-G_{\nu}(x, h, \tilde{v}),
$$

where

$$
\begin{gathered}
Q_{\nu}(x, h)=\left[\begin{array}{cccc}
I & \ldots & 0 & -\left[I+D_{\nu N}(x, N h)\right] \\
I+D_{\nu 1}(x, h) & \ldots & 0 & 0 \\
0 & \ldots & 0 & 0 \\
\ldots & \ldots & \ldots & \ldots \\
0 & \ldots & I+D_{\nu, N-1}(x,(N-1) h) & -I
\end{array}\right], \\
F_{v}(x, h, u)=\left(-F_{v N}\left(x, N h, u_{N}\right), F_{v 1}\left(x, h, u_{1}\right), \ldots, F_{v, N-1}\left(x,(N-1) h, u_{N-1}\right)\right), \\
G_{v}(x, h, \tilde{v})=\left(-G_{v N}\left(x, N h, \tilde{v}_{N}\right), G_{v 1}\left(x, h, \tilde{v}_{1}\right), \ldots, G_{v, N-1}\left(x,(N-1) h, \tilde{v}_{N-1}\right)\right),
\end{gathered}
$$

where $I$ - is a unit matrix of dimension $n$. To find system of three functions

$$
\left\{\lambda_{r}(x), \tilde{v}_{r}(x, t), u_{r}(x, t)\right\}, r=\overline{1, N}
$$

we have a closed system consisting of equations (15), (14) and (12). Assuming the reversibility of the matrix $Q_{v}(x, h)$, for all $x \in[0, \omega]$, from equation (15), where $\tilde{v}_{r}(x, t)=0, u_{r}(x, t)=0$, we find $\lambda^{(0)}(x): \lambda^{(0)}(x)=$ $=-\left[Q_{v}(x, h)\right]^{-1}\left\{F_{v}(x, h, 0)+G_{v}(x, h, 0)\right\}$. Using equation (14), for $\lambda_{r}(x)=\lambda_{r}^{(0)}(x)$ we find the functions $\tilde{v}_{r}^{(0)}(x, t), r=\overline{1, N}$, i.e $\tilde{v}_{r}^{(0)}(x, t)=D_{v r}(x, t) \lambda_{r}^{(0)}(x)+F_{v r}(x, t, \psi)+G_{v r}(x, t, 0)$. 
The functions $u_{r}^{(0)}(x, t), r=\overline{1, N}$, are determined from the relations

$$
u_{r}^{(0)}(x, t)=\int_{0}^{x} \tilde{v}_{r}^{(0)}(\xi, t) d \xi+\int_{0}^{x} \lambda_{r}^{(0)}(\xi) d \xi, \quad(x, t) \in \Omega_{r} .
$$

For the initial approximation of the problem (8)-(12) we take $\lambda_{r}^{(0)}(x), \tilde{v}_{r}^{(0)}(x, t), u_{r}^{(0)}(x, t), r=\overline{1, N}$, and construct successive approximations by the following algorithm:

Step 1. A) Assuming that $u_{r}(x, t)=u_{r}^{(0)}(x, t), r=\overline{1, N}$, are the first approximations in $\lambda_{r}(x), \tilde{v}_{r}(x, t)$ we found by solving the problem (8)-(11).

Taking $\lambda^{(1,0)}(x)=\lambda^{(0)}(x), \tilde{v}_{r}^{(1,0)}(x, t)=\tilde{v}_{r}^{(0)}(x, t)$ system of couple $\left\{\lambda_{r}^{(1)}(x), \tilde{v}_{r}^{(1)}(x, t)\right\}, r=\overline{1, N}$, we find as the limit of the sequence $\lambda_{r}^{(1, m)}(x), \tilde{v}_{r}^{(1, m)}(x, t)$, determined by the following way:

Step 1.1. Assuming the reversibility of the matrix $Q_{v}(x, h)$, for all $x \in[0, \omega]$, from equation (15), where $\tilde{v}_{r}(x, t)=\tilde{v}_{r}^{(1,0)}(x, t)$, we find $\lambda^{(1,1)}(x)$

$$
\lambda^{(1,1)}(x)=-\left[Q_{v}(x, h)\right]^{-1}\left\{F_{v}\left(x, h, u^{(0)}\right)+G_{v}\left(x, h, \tilde{v}^{(1,0)}\right)\right\} .
$$

Substituting the found $\lambda_{r}^{(1,1)}(x), r=\overline{1, N}$ at (14) we find

$$
\tilde{v}_{r}^{(1,1)}(x, t)=D_{v r}(x, t) \lambda_{r}^{(1,1)}(x)+F_{v r}\left(x, t, u^{(0)}\right)+G_{v r}\left(x, t, \tilde{v}^{(1,0)}\right) .
$$

Step 1.2. From equation (15), where $\tilde{v}_{r}(x, t)=\tilde{v}_{r}^{(1,1)}(x, t)$, we define

$$
\lambda^{(1,2)}(x)=-\left[Q_{v}(x, h)\right]^{-1}\left\{F_{v}\left(x, h, u^{(0)}\right)+G_{v}\left(x, h, \tilde{v}^{(1,1)}\right)\right\} .
$$

Using the expression (14) again, we find the functions $\tilde{v}_{r}^{(1,2)}(x, t), r=\overline{1, N}$ :

$$
\tilde{v}_{r}^{(1,2)}(x, t)=D_{v r}(x, t) \lambda_{r}^{(1,2)}(x)+F_{v r}\left(x, t, u^{(0)}\right)+G_{v r}\left(x, t, \tilde{v}^{(1,1)}\right) .
$$

On the $(1, m)$ step, we obtain a system of $\left\{\lambda_{r}^{(1, m)}(x), \tilde{v}_{r}^{(1, m)}(x, t)\right\}, r=\overline{1, N}$.

Assuming that the solution of the problem (8)-(11) is the sequence of a system of couples $\left\{\lambda_{r}^{(1, m)}(x)\right.$, $\left.\tilde{v}_{r}^{(1, m)}(x, t)\right\}$ is defined, and when $m \rightarrow \infty$ converges to the continuous, respectively, on $x \in[0, \omega],(x, t) \in \Omega_{r}$ functions $\lambda_{r}^{(1)}(x), \tilde{v}_{r}^{(1)}(x, t), r=\overline{1, N}$.

B) The functions $u_{r}^{(1)}(x, t), r=\overline{1, N}$, are determined from the ratio

$$
u_{r}^{(1)}(x, t)=\int_{0}^{x} \tilde{v}_{r}^{(1)}(\xi, t) d \xi+\int_{0}^{x} \lambda_{r}^{(1)}(\xi) d \xi,(x, t) \in \Omega_{r} .
$$

Step 2. A) Assuming that $u_{r}(x, t)=u_{r}^{(1)}(x, t), r=\overline{1, N}$, are the first approximations in $\lambda_{r}(x), \tilde{v}_{r}(x, t)$ we find by solving the problem (8)-(11).

Taking $\lambda^{(2,0)}(x)=\lambda^{(1)}(x), \tilde{v}_{r}^{(2,0)}(x, t)=\tilde{v}_{r}^{(1)}(x, t)$ system of couple $\left\{\lambda_{r}^{(2)}(x), \tilde{v}_{r}^{(2)}(x, t)\right\}, r=\overline{1, N}$, we find as the limit of the sequence $\lambda_{r}^{(2, m)}(x), \tilde{v}_{r}^{(2, m)}(x, t)$, defined by the following way:

Step 2.1. Assuming the reversibility of the matrix $Q_{v}(x, h)$, for all $x \in[0, \omega]$, from equation (15), where $\tilde{v}_{r}(x, t)=\tilde{v}_{r}^{(2,0)}(x, t)$, we find $\lambda^{(2,1)}(x)$

$$
\lambda^{(2,1)}(x)=-\left[Q_{v}(x, h)\right]^{-1}\left\{F_{v}\left(x, h, u^{(1)}\right)+G_{v}\left(x, h, \tilde{v}^{(2,0)}\right)\right\} .
$$

Substituting the found $\lambda_{r}^{(2,1)}(x), r=\overline{1, N}$, at (14) we find

$$
\tilde{v}_{r}^{(2,1)}(x, t)=D_{v r}(x, t) \lambda_{r}^{(2,1)}(x)+F_{v r}\left(x, t, u^{(1)}\right)+G_{v r}\left(x, t, \tilde{v}^{(2,0)}\right) .
$$

Step 2.2. From equation (15), where $\tilde{v}_{r}(x, t)=\tilde{v}_{r}^{(2,1)}(x, t)$, we define

$$
\lambda^{(2,2)}(x)=-\left[Q_{v}(x, h)\right]^{-1}\left\{F_{v}\left(x, h, u^{(1)}\right)+G_{v}\left(x, h, \tilde{v}^{(2,1)}\right)\right\} .
$$


Using expression (14) again, we find functions $\tilde{v}_{r}^{(2,2)}(x, t), r=\overline{1, N}$,

$$
\tilde{v}_{r}^{(2,2)}(x, t)=D_{v r}(x, t) \lambda_{r}^{(2,2)}(x)+F_{v r}\left(x, t, u^{(1)}\right)+G_{v r}\left(x, t, \tilde{v}^{(2,1)}\right) .
$$

On the $(2, m)$ step, we obtain a system of couples $\left\{\lambda_{r}^{(2, m)}(x), \tilde{v}_{r}^{(2, m)}(x, t)\right\}, r=\overline{1, N}$.

Assuming that the solution of the problem (8)-(11) is the sequence of a system of couples

$$
\left\{\lambda_{r}^{(2, m)}(x), \tilde{v}_{r}^{(2, m)}(x, t)\right\}
$$

is defined, and when $m \rightarrow \infty$ converges to the continuous, respectively, on $x \in[0, \omega],(x, t) \in \Omega_{r}$ the functions $\lambda_{r}^{(2)}(x), \tilde{v}_{r}^{(2)}(x, t), r=\overline{1, N}$.

B) The functions $u_{r}^{(2)}(x, t), r=\overline{1, N}$, are determined from the ratio

$$
u_{r}^{(2)}(x, t)=\int_{0}^{x} \tilde{v}_{r}^{(2)}(\xi, t) d \xi+\int_{0}^{x} \lambda_{r}^{(2)}(\xi) d \xi,(x, t) \in \Omega_{r} .
$$

And so on. Conditions of the following statement provide the feasibility and convergence of the proposed algorithm, as well as the single-valued solvability of the problem (8)-(12).

Theorem 1. Let for some $h>0: \quad N h=T, N=1,2, \ldots$, and $\nu, \nu=1,2, \ldots, \quad(n N \times n N)-$ the matrix $Q_{\nu}(x, h)$ is reversible for all $x \in[0, \omega]$ and inequalities are satisfied:
1) $\left\|\left[Q_{\nu}(x, h)\right]^{-1}\right\| \leq \gamma_{\nu}(x, h)$
2) $q_{\nu}(x, h)=\frac{(\alpha(x) h)^{\nu}}{\nu !}\left[1+\gamma_{\nu}(x, h) \sum_{j=1}^{\nu} \frac{(\alpha(x) h)^{j}}{j !}\right] \leq \beta<1$.

Then there is only one solution of problem (8)-(12) and valid assessment:

a) $\left\|\lambda^{*}(x)-\lambda^{(0)}(x)\right\|+\sup _{t \in[0, T]}\left\|\tilde{v}^{*}(x, t)-\tilde{v}^{(0)}(x, t)\right\| \leq \rho(x, \nu, h) \sup _{t \in[0, T]}\|f(x, t)\| ;$

b) $\sup _{t \in[0, T]}\left\|u^{*}(x, t)-u^{(0)}(x, t)\right\| \leq \int_{0}^{x}\left(\left\|\lambda^{*}(\xi)-\lambda^{(0)}(\xi)\right\|+\sup _{t \in[0, T]}\left\|\tilde{v}^{*}(\xi, t)-\tilde{v}^{(0)}(\xi, t)\right\|\right) d \xi$,

where $\alpha(x)=\max _{t \in[0, T]}\|A(x, t)\|, \quad \beta=$ const, $b_{1}(x, \nu, h)=\gamma_{v}(x, h) h \sum_{j=0}^{v-1} \frac{(\alpha(x) h)^{j}}{j !}$

$$
\begin{gathered}
b_{2}(x, \nu, h)=\left[1+\gamma_{v}(x, h) \sum_{j=1}^{v} \frac{(\alpha(x) h)^{j}}{j !}\right] h \sum_{j=0}^{v-1} \frac{(\alpha(x) h)^{j}}{j !} ; \\
b_{3}(x, \nu, h)=\gamma_{v}(x, h) \frac{(\alpha(x) h)^{v}}{v !}, \quad d_{1}(x, \nu, h)=\frac{1+b_{3}(x, \nu, h)}{1-q_{v}(x, h)} b_{2}(x, \nu, h)+b_{1}(x, \nu, h) ; \\
d_{2}(x, \nu, h)=\frac{1+b_{3}(x, \nu, h)}{1-q_{v}(x, h)} q_{v}(x, h)+b_{3}(x, \nu, h) ; \\
g(x, \nu, h)=\left[d_{1}(x, \nu, h) \int_{0}^{x}\left[b_{1}(\xi, \nu, h)+b_{2}(\xi, \nu, h)\right] d \xi+d_{2}(x, \nu, h) b_{2}(x, \nu, h)\right] ; \\
\rho(x, \nu, h)=d_{1}(x, \nu, h) \sum_{j=1}^{\infty} \frac{1}{j !}\left(\int_{0}^{x} d_{1}(\xi, \nu, h) d \xi\right)^{j} \int_{0}^{x} g(\xi, \nu, h) d \xi+g(x, \nu, h) .
\end{gathered}
$$

Proof. When assumptions about the data of the problem we have the inequality

$$
\begin{gathered}
\left\|F_{\nu}(x, h, u)\right\| \leq h \sum_{j=0}^{\nu-1} \frac{(\alpha(x) h)^{j}}{j !} \max _{r=\overline{1, N}} \sup _{t \in[(r-1) h, r h)}\left\|u_{r}(x, t)\right\|+\|f(x, t)\| ; \\
\left\|G_{\nu}(x, h, \widetilde{v})\right\| \leq \frac{(\alpha(x) h)^{\nu}}{\nu !} \max _{r=1, N} \sup _{t \in[(r-1) h, r h)}\left\|\widetilde{v}_{r}(x, t)\right\| ;
\end{gathered}
$$




$$
\max _{r=1, N} \sup _{t \in[(r-1) h, r h)}\left\|D_{\nu r}(x, t)\right\| \leq \sum_{j=1}^{\nu} \frac{(\alpha(x) h)^{j}}{j !} .
$$

The following estimates follow from the zero step of the algorithm:

$$
\begin{gathered}
\max _{r=\overline{1, N}}\left\|\lambda_{r}{ }^{(0)}(x)\right\| \leq b_{1}(x, \nu, h) \max _{t \in[0, T]}\|f(x, t)\| ; \\
\max _{r=\overline{1, N}} \sup _{t \in[(r-1) h, r h)}\left\|\widetilde{v}_{r}^{(0)}(x, t)\right\| \leq b_{2}(x, \nu, h) \max _{t \in[0, T]}\|f(x, t)\| ; \\
\max _{r=\overline{1, N}} \sup _{t \in[(r-1) h, r h)}\left\|u_{r}^{(0)}(x, t)\right\| \leq \int_{0}^{x}\left[b_{1}(\xi, \nu, h)+b_{2}(\xi, \nu, h)\right] d \xi \max _{(x, t) \in \bar{\Omega}}\|f(\xi, t)\| .
\end{gathered}
$$

The following estimates are valid:

$$
\begin{gathered}
\max _{r=1, N}\left\|\lambda_{r}^{(1,1)}(x)-\lambda_{r}{ }^{(1,0)}(x)\right\| \leq \\
\leq b_{1}(x, \nu, h) \max _{r=\overline{1, N}} \sup _{t \in[(r-1) h, r h)}\left\|u_{r}^{(0)}(x, t)\right\|+b_{3}(x, \nu, h) \max _{r=\overline{1, N}} \sup _{t \in[(r-1) h, r h)}\left\|\widetilde{v}_{r}^{(0)}(x, t)\right\| ; \\
\max _{r=1, N} \sup _{t \in[(r-1) h, r h)}\left\|\widetilde{v}_{r}^{(1,1)}(x, t)-\widetilde{v}_{r}^{(1,0)}(x, t)\right\| \leq \\
\leq b_{2}(x, \nu, h) \max _{r=\overline{1, N}} \sup _{t \in[(r-1) h, r h)}\left\|u_{r}^{(0)}(x, t)\right\|+q_{\nu}(x, h) \max _{r=\overline{1, N}} \sup _{t \in[(r-1) h, r h)}\left\|\widetilde{v}_{r}^{(0)}(x, t)\right\| .
\end{gathered}
$$

Select the inequality

$$
\begin{gathered}
\Delta^{(1,1)}(x)=\max _{r=1, N} \sup _{t \in[(r-1) h, r h)}\left\|\widetilde{v}_{r}^{(1,1)}(x, t)-\widetilde{v}_{r}^{(1,0)}(x, t)\right\|+\max _{r=\overline{1, N}}\left\|\lambda_{r}{ }^{(1,1)}(x)-\lambda_{r}{ }^{(1,0)}(x)\right\| \leq \\
\leq\left[b_{1}(x, \nu, h)+b_{2}(x, \nu, h)\right] \int_{0}^{x}\left[b_{1}(\xi, \nu, h)+b_{2}(\xi, \nu, h)\right] d \xi \max _{(x, t) \in \bar{\Omega}}\|f(x, t)\|+ \\
+\left[b_{3}(x, \nu, h)+q_{\nu}(x, h)\right] b_{2}(x, \nu, h) \max _{(x, t) \in \bar{\Omega}}\|f(x, t)\| .
\end{gathered}
$$

Thus,

$$
\begin{gathered}
\max _{r=1, N}\left\|\lambda_{r}^{(1, m+1)}(x)-\lambda_{r}^{(1, m)}(x)\right\| \leq \\
\leq b_{3}(x, \nu, h) \max _{r=\overline{1, N}} \sup _{t \in[(r-1) h, r h)}\left\|\widetilde{v}_{r}^{(1, m)}(x, t)-\widetilde{v}_{r}^{(1, m-1)}(x, t)\right\| ; \\
\max _{r=1, N} \sup _{t \in[(r-1) h, r h)}\left\|\widetilde{v}_{r}^{(1, m+1)}(x, t)-\widetilde{v}_{r}^{(1, m)}(x, t)\right\| \leq \\
\leq q_{\nu}(x, h) \max _{r=\overline{1, N}} \sup _{t \in[(r-1) h, r h)}\left\|\widetilde{v}_{r}^{(1, m)}(x, t)-\widetilde{v}_{r}^{(1, m-1)}(x, t)\right\| .
\end{gathered}
$$

Due to the inequality $q_{\nu}(x, h)<1$ follows the uniform convergence $v_{r}^{(1, m+1)}(x, t)$, at $(x, t) \in \Omega_{r}$, to $v_{r}^{(1)}(x, t)$ and the convergence of a sequence of systems of functions $\lambda_{r}^{(1, m+1)}(x)$ to continuous $x \in[0, \omega]$ functions $\lambda_{r}^{(1)}(x)$ for all $r=\overline{1, N}$ :

$$
\begin{gathered}
\max _{r=1, N} \sup _{t \in[(r-1) h, r h)}\left\|\widetilde{v}_{r}^{(1, m+1)}(x, t)-\widetilde{v}_{r}^{(1,0)}(x, t)\right\| \leq \\
\leq \sum_{j=0}^{m}\left[q_{\nu}(x, h)\right]^{j} \max _{r=\overline{1, N}} \sup _{t \in[(r-1) h, r h)}\left\|\widetilde{v}_{r}^{(1,1)}(x, t)-\widetilde{v}_{r}^{(1,0)}(x, t)\right\| ; \\
\max _{r=\overline{1, N}}\left\|\lambda_{r}{ }^{(1, m+1)}(x)-\lambda_{r}^{(1,0)}(x)\right\| \leq
\end{gathered}
$$




$$
\begin{gathered}
\leq b_{3}(x, \nu, h) \sum_{j=0}^{m}\left[q_{\nu}(x, h)\right]^{j} \max _{r=\overline{1, N}} \sup _{t \in[(r-1) h, r h)}\left\|\widetilde{v}_{r}^{(1,1)}(x, t)-\widetilde{v}_{r}^{(1,0)}(x, t)\right\|+ \\
+\max _{r=\overline{1, N}}\left\|\lambda_{r}^{(1,1)}(x)-\lambda_{r}^{(1,0)}(x)\right\| ; \\
\max _{r=\overline{1, N}} \sup _{t \in[(r-1) h, r h)}\left\|\widetilde{v}_{r}^{(1, m+1)}(x, t)-\widetilde{v}_{r}^{(1,0)}(x, t)\right\|+\max _{r=1, N}\left\|\lambda_{r}{ }^{(1, m+1)}(x)-\lambda_{r}^{(1,0)}(x)\right\| \leq \\
\leq\left[1+b_{3}(x, \nu, h)\right] \sum_{j=0}^{m}\left[q_{\nu}(x, h)\right]^{j} \max _{r=1, N} \sup _{t \in[(r-1) h, r h)}\left\|\widetilde{v}_{r}^{(1,1)}(x, t)-\widetilde{v}_{r}^{(1,0)}(x, t)\right\|+ \\
+\max _{r=\overline{1, N}}\left\|\lambda_{r}^{(1,1)}(x)-\lambda_{r}{ }^{(1,0)}(x)\right\| .
\end{gathered}
$$

Moving to the limit at $m \rightarrow \infty$, we obtain estimates:

$$
\begin{gathered}
\Delta^{(1)}(x)=\max _{r=\overline{1, N}} \sup _{t \in[(r-1) h, r h)}\left\|\widetilde{v}_{r}^{(1)}(x, t)-\widetilde{v}_{r}^{(0)}(x, t)\right\|+ \\
+\max _{r=\overline{1, N}}\left\|\lambda_{r}^{(1)}(x)-\lambda_{r}^{(0)}(x)\right\| \leq g(x, \nu, h) \max _{t \in[0, T]}\|f(x, t)\| ; \\
\max _{r=1, N} \sup _{t \in[(r-1) h, r h)}\left\|u_{r}^{(1)}(x, t)-u_{r}^{(0)}(x, t)\right\| \leq \int_{0}^{x} \Delta^{(1)}(\xi) d \xi .
\end{gathered}
$$

For difference systems $\lambda_{r}{ }^{(k+1)}(x)-\lambda_{r}{ }^{(k)}(x), \widetilde{v}_{r}^{(k+1)}(x, t)-\widetilde{v}_{r}^{(k)}(x, t), u_{r}^{(k+1)}(x, t)-u_{r}^{(k)}(x, t), r=\overline{1, N}$, $k=1,2, \ldots$, valid estimates:

$$
\begin{gathered}
\max _{r=\overline{1, N}}\left\|\lambda_{r}{ }^{(k+1,1)}(x)-\lambda_{r}{ }^{(k+1,0)}(x)\right\| \leq \\
\leq b_{1}(x, \nu, h) \max _{r=\overline{1, N}} \sup _{t \in[(r-1) h, r h)}\left\|u_{r}^{(k)}(x, t)-u_{r}^{(k-1)}(x, t)\right\| ; \\
\max _{r=1, N} \sup _{t \in[(r-1) h, r h)}\left\|\widetilde{v}_{r}^{(k+1,1)}(x, t)-\widetilde{v}_{r}^{(k+1,0)}(x, t)\right\| \leq \\
\leq b_{2}(x, \nu, h) \max _{r=\overline{1, N}} \sup _{t \in[(r-1) h, r h)}\left\|u_{r}^{(k)}(x, t)-u_{r}^{(k-1)}(x, t)\right\| ; \\
\max _{r=1, N}\left\|\lambda_{r}^{(k+1, m+1)}(x)-\lambda_{r}^{(k+1, m)}(x)\right\| \leq \\
\leq b_{3}(x, \nu, h) \max _{r=\overline{1, N}} \sup _{t \in[(r-1) h, r h)}\left\|\widetilde{v}_{r}^{(k+1, m)}(x, t)-\widetilde{v}_{r}^{(k+1, m-1)}(x, t)\right\| ; \\
\max _{r=\overline{1, N}} \sup _{t \in[(r-1) h, r h)}\left\|\widetilde{v}_{r}^{(k+1, m+1)}(x, t)-\widetilde{v}_{r}^{(k+1, m)}(x, t)\right\| \leq \\
\leq q_{\nu}(x, h) \max _{r=\overline{1, N}} \sup _{t \in[(r-1) h, r h)}\left\|\widetilde{v}_{r}^{(k+1, m)}(x, t)-\widetilde{v}_{r}^{(k+1, m-1)}(x, t)\right\| ; \\
\max _{r=\overline{1, N}} \sup _{t \in[(r-1) h, r h)}\left\|\widetilde{v}_{r}^{(k+1, m+1)}(x, t)-\widetilde{v}_{r}^{(k+1,0)}(x, t)\right\| \leq \\
\leq \sum_{j=0}^{m}\left[q_{\nu}(x, h)\right]^{j} \max _{r=\overline{1, N}} \sup _{t \in[(r-1) h, r h)}\left\|\widetilde{v}_{r}^{(k+1,1)}(x, t)-\widetilde{v}_{r}^{(k+1,0)}(x, t)\right\| ; \\
\max _{r=\overline{1, N}}\left\|\lambda_{r}(k+1, m+1)(x)-\lambda_{r}{ }^{(k+1,0)}(x)\right\| \leq \\
b_{3}(x, \nu, h) \sum_{j=0}^{m-1}\left[q_{\nu}(x, h)\right]^{j} \max _{r=1, N} \sup _{t \in[(r-1) h, r h)}\left\|\widetilde{v}_{r}^{(k+1,1)}(x, t)-\widetilde{v}_{r}^{(k+1,0)}(x, t)\right\|+
\end{gathered}
$$




$$
+\max _{r=1, N}\left\|\lambda_{r}^{(k+1,1)}(x)-\lambda_{r}^{(k+1,0)}(x)\right\| .
$$

Moving to the limit at $m \rightarrow \infty$, we obtain estimates:

$$
\begin{gathered}
\max _{r=\overline{1, N}} \sup _{t \in[(r-1) h, r h)}\left\|\widetilde{v}_{r}^{(k+1)}(x, t)-\widetilde{v}_{r}^{(k)}(x, t)\right\| \leq \\
\leq \frac{b_{2}(x, \nu, h)}{1-q_{\nu}(x, h)} \max _{r=\overline{1, N}} \sup _{t \in[(r-1) h, r h)}\left\|u_{r}^{(k)}(x, t)-u_{r}^{(k-1)}(x, t)\right\| ; \\
\max _{r=1, N}\left\|\lambda_{r}{ }^{(k+1)}(x)-\lambda_{r}^{(k)}(x)\right\| \leq \\
\leq\left[\frac{b_{3}(x, \nu, h)}{1-q_{\nu}(x, h)} b_{2}(x, \nu, h)+b_{1}(x, \nu, h)\right] \max _{r=1, N} \sup _{t \in[(r-1) h, r h)}\left\|u_{r}^{(k)}(x, t)-u_{r}^{(k-1)}(x, t)\right\| ; \\
\max _{r=\overline{1, N}} \sup _{t \in[(r-1) h, r h)}\left\|u_{r}^{(k+1)}(x, t)-u_{r}^{(k)}(x, t)\right\| \leq \\
\leq \int_{0}^{x}\left[\max _{r=1, N}\left\|\lambda_{r}{ }^{(k+1)}(\xi)-\lambda_{r}{ }^{(k)}(\xi)\right\|+\max _{r=1, N} \sup _{t \in[(r-1) h, r h)}\left\|\widetilde{v}_{r}^{(k+1)}(\xi, t)-\widetilde{v}_{r}^{(k)}(\xi, t)\right\|\right] d \xi .
\end{gathered}
$$

Summing, respectively, the left and right parts of inequalities (16), (17) we have

$$
\begin{gathered}
\Delta^{(k+1)}(x)=\max _{r=\overline{1, N}} \sup _{t \in[(r-1) h, r h)}\left\|\widetilde{v}_{r}^{(k+1)}(x, t)-\widetilde{v}_{r}^{(k)}(x, t)\right\|+\max _{r=\overline{1, N}}\left\|\lambda_{r}{ }^{(k+1)}(x)-\lambda_{r}{ }^{(k)}(x)\right\| \leq \\
\leq d_{1}(x, \nu, h) \max _{r=\overline{1, N}} \sup _{t \in[(r-1) h, r h)}\left\|u_{r}^{(k)}(x, t)-u_{r}^{(k-1)}(x, t)\right\| ; \\
\max _{r=\overline{1, N}} \sup _{t \in[(r-1) h, r h)}\left\|u_{r}^{(k+1)}(x, t)-u_{r}^{(k)}(x, t)\right\| \leq \int_{0}^{x} \Delta^{(k+1)}(\xi) d \xi .
\end{gathered}
$$

For function $\Delta^{(k+1)}(x)$ based on (18) we obtain inequalities

$$
\begin{gathered}
\Delta^{(k+1)}(x) \leq d_{1}(x, \nu, h) \int_{0}^{x} \Delta^{(k)}(\xi) d \xi \\
\Delta^{(k)}(x) \leq \frac{d_{1}(x, \nu, h)}{(k-1) !}\left(\int_{0}^{x} z(\xi) L(\xi) d \xi\right)^{k-1} \int_{0}^{x} \Delta^{(1)}(\xi) d \xi .
\end{gathered}
$$

Set the inequalities

$$
\begin{gathered}
\max _{r=1, N}\left\|\lambda_{r}^{(k+p)}(x)-\lambda_{r}^{(0)}(x)\right\|+\max _{r=1, N} \sup _{t \in[(r-1) h, r h)}\left\|\widetilde{v}_{r}^{(k+p)}(x, t)-\widetilde{v}_{r}^{(0)}(x, t)\right\| \leq \\
\leq \Delta^{(k+p)}(x)+\Delta^{(k+p-1)}(x)+\ldots+\Delta^{(1)}(x) \leq \\
\leq d_{1}(x, \nu, h) \sum_{j=1}^{p} \frac{1}{j !}\left(\int_{0}^{x} d_{1}(\xi, \nu, h) d \xi\right)^{j} \int_{0}^{x} \Delta^{(1)}(\xi) d \xi+\Delta^{(1)}(x) \leq \\
\leq\left[d_{1}(x, \nu, h) \sum_{j=1}^{p} \frac{1}{j !}\left(\int_{0}^{x} d_{1}(\xi, \nu, h) d \xi\right)^{j} \int_{0}^{x} g(\xi, \nu, h) d \xi+g(x, \nu, h)\right] \max _{(x, t) \in \bar{\Omega}}\|f(x, t)\| ; \\
\max _{r=1, N} \sup _{t \in[(r-1) h, r h)}\left\|u_{r}^{(k+p)}(x, t)-u_{r}^{(0)}(x, t)\right\| \leq
\end{gathered}
$$




$$
\leq \int_{0}^{x}\left[\max _{r=1, N}\left\|\lambda_{r}^{(k+p)}(\xi)-\lambda_{r}^{(0)}(\xi)\right\|+\max _{r=\overline{1, N}} \sup _{t \in[(r-1) h, r h)}\left\|\widetilde{v}_{r}^{(k+1)}(\xi, t)-\widetilde{v}_{r}^{(0)}(\xi, t)\right\|\right] d \xi .
$$

At $p \rightarrow \infty$, we obtain the estimates of Theorem 1. The uniqueness of the solution is proved analogously to the uniqueness of Theorem 1 [9]. Theorem 1 is proved.

Theorem 2. Let the conditions of Theorem 1 be fulfilled. Then the problem (4)-(6) has a unique solution $u^{*}(x, t)$.

\section{Main result}

Now let us return to this duo-periodic problem Denote by $\mu(t)$ the value of the unknown function $z(x, t)$ for $x=0$ and perform the replacement $u(x, t)=z(x, t)-\mu(t)$. Then the problem (1)-(3) is reduced to the following equivalent problem with the functional parameter

$$
\begin{gathered}
\frac{\partial^{2} u}{\partial x \partial t}=A(x, t) \frac{\partial u}{\partial x}+u+\mu(t)+f(x, t), \quad(x, t) \in \Omega ; \\
u(0, t)=0, \quad t \in[0, T] ; \\
u(x, 0)=u(x, T), \quad x \in[0, \omega] \\
u(\omega, t)=0, \quad t \in[0, T] ; \\
\mu(0)=\mu(T) .
\end{gathered}
$$

By virtue of (23) the equality $u(x, 0)+\mu(0)=u(x, T)+\mu(T)$ which follows from (3) is written in the form (21). With the found $\mu(t)$ the function $u(x, t)$ is a solution of the periodic boundary value problem (19)-(21). To solve the problem (19)-(21) we use the method of a parametrization. Since conditions (20), (22) imply the equality $\frac{\partial u(0, t)}{\partial t}=0, \frac{\partial u(\omega, t)}{\partial t}=0$, for all $t \in[0, T]$, then integrating both parts (19) by $x \in[0, \omega]$ we obtain a system of differential equations, not resolved with respect to the derivative, to determine the unknown function $\mu(t)$ :

$$
\mu(t)=-\frac{1}{\omega} \int_{0}^{\omega} A(\xi, t) \frac{\partial u(\xi, t)}{\partial x} d \xi-\frac{1}{\omega} \int_{0}^{\omega} u(\xi, t) d \xi-\frac{1}{\omega} \int_{0}^{\omega} f(\xi, t) d \xi .
$$

Thus, to determine the unknown functions $v(x, t), u(x, t), \mu(t)$ we have a closed system of equations (19)-(21) and (24).

Assuming that $u(x, t)=0$, from equation (19) we find $\mu^{(0)}(t)$. Suppose that the problem (19)-(21) for $\mu(t)=\mu^{(0)}(t)$ has a solution $u^{(0)}(x, t) \in C\left(\bar{\Omega}, R^{n}\right)$.

For the initial approximation of problem (19)-(21) we take a pair $\left\{\mu^{(0)}(t), u^{(0)}(x, t)\right\}$ and construct successive approximations using the following algorithm:

Step 1. Assuming that $u(x, t)=u^{(0)}(x, t)$ from equation (24) we find $\mu^{(1)}(t)$ :

$$
\mu^{(1)}(t)=-\frac{1}{\omega} \int_{0}^{\omega} A(\xi, t) \frac{\partial u^{(0)}(\xi, t)}{\partial x} d \xi-\frac{1}{\omega} \int_{0}^{\omega} u^{(0)}(\xi, t) d \xi-\frac{1}{\omega} \int_{0}^{\omega} f(\xi, t) d \xi .
$$

The function $u^{(1)}(x, t)$ is defined as the solution of a periodic boundary value problem

$$
\begin{gathered}
\frac{\partial^{2} u}{\partial x \partial t}=A(x, t) \frac{\partial u}{\partial x}+u+\mu^{(1)}(t)+f(x, t), \quad(x, t) \in \Omega ; \\
u(0, t)=0, \quad t \in[0, T] ; \\
u(x, 0)=u(x, T), \quad x \in[0, \omega] .
\end{gathered}
$$

To solve a periodic boundary value problem, we use the method of a parametrization.

Step 2. Assuming that $u(x, t)=u^{(1)}(x, t)$ from equation (24) we find $\mu^{(2)}(t)$

$$
\mu^{(2)}(t)=-\frac{1}{\omega} \int_{0}^{\omega} A(\xi, t) \frac{\partial u^{(1)}(\xi, t)}{\partial x} d \xi-\frac{1}{\omega} \int_{0}^{\omega} u^{(1)}(\xi, t) d \xi-\frac{1}{\omega} \int_{0}^{\omega} f(\xi, t) d \xi .
$$


The function $u^{(2)}(x, t)$ is defined as the solution of a periodic boundary value problem

$$
\begin{gathered}
\frac{\partial^{2} u}{\partial x \partial t}=A(x, t) \frac{\partial u}{\partial x}+u+\mu^{(2)}(t)+f(x, t), \quad(x, t) \in \Omega ; \\
u(0, t)=0, \quad y \in[0, T] ; \\
u(x, 0)=u(x, T), \quad x \in[0, \omega] .
\end{gathered}
$$

To solve a periodic boundary value problem, we use the method of a parametrization. And so on.

Continuing the process, at the $k$ step we obtain the system $\left(\mu^{(k)}(t), u^{(k)}(x, t)\right)$.

Sufficient conditions for feasibility, convergence of the proposed algorithm establishes

Theorem 3. Let for some $h>0: N h=T, N=1,2, \ldots$ and $\nu, \nu=1,2, \ldots,(n N \times n N)$ - matrix $Q_{\nu}(x, h)$ is reversible for all $x \in[0, \omega]$ and the inequalities hold:

1) $\left\|\left[Q_{\nu}(x, h)\right]^{-1}\right\| \leq \gamma_{\nu}(x, h)$

2) $q_{\nu}(x, h)=\frac{(\alpha(x) h)^{\nu}}{\nu !}\left[1+\gamma_{\nu}(x, h) \sum_{j=1}^{\nu} \frac{(\alpha(x) h)^{j}}{j !}\right] \leq \beta<1$;

3) $\theta(x, \nu, h)=\alpha(x) \rho(x, \nu, h)+\int_{0}^{x} \alpha(\xi) \rho(\xi, \nu, h) d \xi<\sigma<1$.

Then the duo-periodic boundary value problem (1)-(3) has a unique solution.

Proof. According to Theorem 1, there are estimates

$$
\begin{gathered}
\left\|\lambda^{(1, *)}(x)-\lambda^{(1,0)}(x)\right\|+\sup _{t \in[0, T]}\left\|\tilde{v}^{(1, *)}(x, t)-v^{(1,0)}(x, t)\right\| \leq \\
\leq \rho(x, \nu, h) \sup _{t \in[0, T]}\left[\left\|\mu^{(1.0)}(t)\right\|+\|f(x, t)\|\right] ; \\
\sup _{t \in[0, T]}\left\|u^{(1 . *)}(x, t)-u^{(1.0)}(x, t)\right\| \leq \int_{0}^{x}\left\|\lambda^{(1 . *)}(\xi)-\lambda^{(1,0)}(\xi)\right\| d \xi+ \\
+\int_{0}^{x} \sup _{t \in[0, T]}\left\|\tilde{v}^{(1 . *)}(\xi, t)-v^{(1.0)}(\xi, t)\right\| d \xi,
\end{gathered}
$$

here $\lambda^{(1,0)}(x)=\lambda^{(0)}(x), \tilde{v}^{(1.0)}(x, t)=\tilde{v}^{(0)}(x, t), u^{(1.0)}(x, t)=u^{(0)}(x, t), \mu^{(1.0)}(t)=\mu^{(0)}(t), \lambda^{(1 . *)}(x)=\lambda^{(1)}(x)$, $\tilde{v}^{(1 . *)}(x, t)=\tilde{v}^{(1)}(x, t), u^{(1 . *)}(x, t)=u^{(1)}(x, t)$, then inequalities $(25),(26)$ are rewritten as

$$
\begin{gathered}
\left\|\lambda^{(1)}(x)-\lambda^{(0)}(x)\right\|+\sup _{t \in[0, T]}\left\|\tilde{v}^{(1)}(x, t)-v^{(0)}(x, t)\right\| \leq \\
\leq \rho(x, \nu, h) \sup _{t \in[0, T]}\left\|\mu^{(0)}(t)\right\|+\rho(x, \nu, h) \sup _{t \in[0, T]}\|f(x, t)\| ; \\
\sup _{t \in[0, T]}\left\|u^{(1)}(x, t)-u^{(0)}(x, t)\right\| \leq \\
\leq \int_{0}^{x} \rho(\xi, \nu, h) d \xi \cdot \sup _{t \in[0, T]}\left\|\mu^{(0)}(t)\right\|+\int_{0}^{x} \rho(\xi, \nu, h) \cdot \sup _{t \in[0, T]}\|f(\xi, t)\| d \xi .
\end{gathered}
$$

Valid assessment

$$
\begin{gathered}
\left\|\mu^{(1)}(t)-\mu^{(0)}(t)\right\| \leq \alpha(x) \rho(x, \nu, h) \sup _{t \in[0, T]}\left\|\mu^{(0)}(t)\right\|+\alpha(x) \rho(x, \nu, h) \sup _{t \in[0, T]}\|f(x, t)\|+ \\
+\int_{0}^{x} \rho(\xi, \nu, h) d \xi \cdot \sup _{t \in[0, T]}\left\|\mu^{(0)}(t)\right\|+\int_{0}^{x} \rho(\xi, \nu, h) \cdot \sup _{t \in[0, T]}\|f(\xi, t)\| d \xi .
\end{gathered}
$$

At the $k$ step we obtain a system

$$
\left\|\lambda^{(k)}(x)-\lambda^{(k-1)}(x)\right\|+\sup _{t \in[0, T]}\left\|\tilde{v}^{(k)}(x, t)-v^{(k-1)}(x, t)\right\| \leq
$$




$$
\begin{gathered}
\leq \rho(x, \nu, h) \sup _{t \in[0, T]}\left\|\mu^{(k-1)}(t)-\mu^{(k-2)}(t)\right\| ; \\
\sup _{t \in[0, T]}\left\|u^{(k)}(x, t)-u^{(k-1)}(x, t)\right\| \leq \\
\leq \int_{0}^{x}\left(\left\|\lambda^{(k)}(\xi)-\lambda^{(k-1)}(\xi)\right\|+\sup _{t \in[0, T]}\left\|\tilde{v}^{(k)}(\xi, t)-v^{(k-1)}(\xi, t)\right\|\right) d \xi ; \\
\left\|\mu^{(k)}(t)-\mu^{(k-1)}(t)\right\| \leq[\theta(x, \nu, h)]^{k} \sup _{t \in[0, T]}\left\|\mu^{(1)}(t)-\mu^{(0)}(t)\right\|,
\end{gathered}
$$

$k=2,3, \ldots$. Due to the inequality $\theta(x, \nu, h)<1$ follows the uniform convergence of $u^{(k)}(x, t), \tilde{v}^{(k)}(x, t),(x, t) \in \bar{\Omega}$ to $u^{*}(x, t), v^{*}(x, t)$ and the convergence of a sequence of systems of functions $\lambda^{(k)}(x), \mu^{(k)}(t)$ to the continuous, respectively, on $x \in[0, \omega], t \in[0, T]$ to the functions $\lambda^{*}(x), \mu^{*}(t)$.

The uniqueness of the solution is proved analogously to the uniqueness of Theorem 1 [9]. Theorem 3 is proved.

The work was supported by grant funding of scientific research by the Committee of Science of the Ministry of Education and Science of the Republic of Kazakhstan (project no. AR05132262 CS MES RK).

\section{References}

1 Cesari L.F. Criterion for the existence in a strip of periodic solutions of hyperbolic partial differential equations / L.F. Cesari // Rend. Circ. Mat. Palermo. - 1965. - Vol. 14. - No. 2. - P. 95-118.

2 Hale J.K. Periodic solutions of a class of hyperbolic equations containing a small parameter / J.K. Hale // Arch.Rational Meth.Anal. - 1967. - Vol. 14. - No. 5. - P. 380-398.

3 Hesquet G. Utilisation de la methode d'Euler - cauchy pour la demonstration d'un theoreme de L.Cesari / G. Hesquet // C.R.Acad. Sci. Paris. Ser. A. - 1971. - Vol. 273. - P. 712-715.

4 Aziz A. K. Periodic solutions of hyperbolic partial differential equations / A. K. Aziz // Proc. Amer. Math. Soc. - 1966. - Vol. 17. - P. 557-566.

5 Kiguradze T. On doubly periodic solutions of fourth - order linear hyperbolic equations / T. Kiguradze, V. Lakshmikantham // Nonlinear Analysis. - 2002. - Vol. 49. - No. 1. - P. 87-112.

6 Dzhumabaev Dulat S. On one approach to solve the linear boundary value problems for Fredholm integrodifferential equations / Dulat S. Dzhumabaev // Journal of Computational and Applied Mathematics. 2016. - Vol. 294. - P. 342-357. DOI: 10.1016/j.cam.2015.08.023.

7 Dzhumabaev D.S. Well-posedness of nonlocal boundary value problem for a system of loaded hyperbolic equations and an algorithm for finding its solution / D.S. Dzhumabaev // Journal of Mathematical analysis and Applications. - 2018. - Vol. 461. - No. 1. - P. 817-836. DOI: 10.1016/j.jmaa.2017.12.005.

8 Assanova A.T. On a Nonlocal Problem with Integral Conditions for the System of Hyperbolic Equations / A.T. Assanova // Differential equations. - 2018. - Vol. 54. - No 2. - P. 201-214. DOI: 10.1134/S0012266118020076.

9 Assanova A.T. Nonlocal Problem with Integral Conditions for a System of Hyperbolic Equations in Characteristic Rectangle / A.T. Assanova // Russian mathematics. - 2018. - Vol. 61. - No. 5. P. 7-20. DOI: 10.3103/S1066369X17050024.

10 Орумбаева Н.Т. Об одном алгоритме нахождения решения периодической краевой задачи для системы квазилинейных гиперболических уравнений / Н.Т. Орумбаева // Сибирские электронные математические известия. - 2013. - Т. 10. - C. 464-474. DOI: 10.17377/semi.2013.10.036.

11 Orumbayeva N.T. On solvability of non-linear semi-periodic boundary-value problem for system of hyperbolic equations / N.T. Orumbayeva // Russian Mathematics (Iz. VUZ). - 2016. - No. 9. - P. 26-41.

12 Orumbayeva N. On a method of finding a solution of semi-periodic boundary value problem for hyperbolic equations / N. Orumbayeva, B. Shayakhmetova // AIP Conference Proceedings. - 2016. - Vol. 1759. - P. 020121. DOI:10.1063/1.4959735. 
13 Orumbayeva N.T. Algorithms for finding a solution to the initial boundary value problems for differential equations in partial derivatives / N.T. Orumbayeva // Bulletin of the Karaganda University-Mathematics. - 2016. - No. 2 (82). - P. 107-112.

14 Orumbayeva N.T. A boundary value problem for nonlinear differential equation with arbitrary functions / N.T. Orumbayeva, G. Sabitbekova // Bulletin of the Karaganda University-Mathematics. - 2017. No. 1 (85). - P. 71-76. DOI: 10.31489/2017M1/71-76.

15 Orumbayeva N.T. On a Solution of a Nonlinear Semi-periodic Boundary Value Problem for a Differential Equation with Arbitrary Functions / N.T. Orumbayeva, G. Sabitbekova // Springer Proceedings in Mathematics and Statistics. - 2017. - Vol. 216. - P. 158-163.

16 Assanova A.T. Well-posedness of a periodic boundary value problem for the system of hyperbolic equations with delayed argument / A.T. Assanova, N.B. Iskakova, N.T. Orumbayeva // Bulletin of the Karaganda University-Mathematics. - 2018. - No 1 (89). - P. 8-14. DOI: 10.31489/2018M1/8-14.

\section{Н.Т. Орумбаева, А.Б. Кельдибекова}

\section{Аралас туындылы гиперболалық теңдеулер жүйесі үшін қос периодты есептің шешімділігі жайында}

Екінші ретті гиперболалық теңдеулер теориясының негізгі және неғұрлым зерттелген есептерінің бірі периодты шеттік есеп болып табылады. Мұндай есептерді шешу үшін Фурье әдісі, біртіндеп жуықтау әдісі, функционалдық талдау әдістері, вариациялық әдіс және т.б. қолданылады. Осындай конструктивтік әдістердің бірі қарапайым дифференциалдық теңдеулердің екі нүктелі шеттік есептерін шешу үшін Д.С. Джумабаевтың жұмыстарында ұсынылған параметрлеу әдісі болып табылады. Ұсынылып отырған жұмыста аралас туындылы гиперболалық теңдеулер жүйесі үшін екі айнымалы бойынша периодты шеттік есеп қарастырылған. Осы есепті шешу үшін жаңа функциялар енгізілді және периодты шеттік есеп қарапайым дифференциалдық теңдеулер үйірі мен интегралдық теңдеуден тұратын эквивалентті есепке келтірілді. Алынған есепті шешу үшін параметрлеу әдісі қолданылады. Бұл әдісті пайдалану аралас туындылы гиперболалық теңдеулер жүйесі үшін периодты шеттік есептің шешімін табу алгоритмін құруға мүмкіндік берді. Сонымен қатар ұсынылған алгоритмнің жинақтылығы мен орындалуының коэффициентті шарттары алынды.

Kiлm сөздер: қос периодты есеп, параметірлік әдіс, гиперболалық теңдеулер жүйесі, аралас туынды.

Н.Т. Орумбаева, А.Б. Кельдибекова

\section{О разрешимости двоякопериодической задачи для системы гиперболических уравнений со смешанной производной}

Одной из основных и наиболее изученных задач теории гиперболических уравнений второго порядка является периодическая краевая задача. Для решения таких задач применяются метод Фурье, метод последовательных приближений, методы функционального анализа, вариационный метод и др. Развитие информационных технологий предъявляет новые требования на разрабатываемые методы, уделяя особое внимание их конструктивности. Одним из таких конструктивных методов является метод параметризации, предложенный в работах Д.С. Джумабаева, для решения двухточечных краевых задач обыкновенных дифференциальных уравнений. В данной работе рассмотрена периодическая по обеим переменным краевая задача для системы гиперболических уравнений со смешанной производной. Для решения данной задачи вводятся обозначения и периодическая краевая задача сводится к эквивалентной задаче, состоящей из семейства периодических краевых задач для обыкновенного дифференциального уравнения и интегрального соотношения. Для решения полученной задачи применяется метод параметризации. Применение данного метода позволило построить алгоритм нахождения приближенного решения периодической краевой задачи для системы гиперболических уравнений со 
смешанной производной. Кроме того, получены коэффициентные условия сходимости и осуществимости предложенного алгоритма.

Ключевые слова: двоякопериодическая краевая задача, метод параметризации, система гиперболических уравнений, смешанные производные.

\section{References}

1 Cesari, L.F. (1965). Criterion for the existence in a strip of periodic solutions of hyperbolic partial differential equations. Rend. Circ. Mat. Palermo. 14, No. 2, 95-118.

2 Hale, J.K. (1967). Periodic solutions of a class of hyperbolic equations containing a small parameter. Arch. Rational Meth. Anal., Vol. 14, 5, 380-398.

3 Hesquet, G. (1971). Utilisation de la methode d'Euler - cauchy pour la demonstration d'un theoreme de L.Cesari, C. R. Acad. Sci. Paris. Ser. A. 273, 712-715.

4 Aziz, A.K. (1966). Periodic solutions of hyperbolic partial differential equations. Proc. Amer. Math. Soc. Vol. $17,557-566$.

5 Kiguradze, T., \& Lakshmikantham, V. (2002). On doubly periodic solutions of fourth - order linear hyperbolic equations. Nonlinear Analysis, Vol. 49, 1, 87-112.

6 Dzhumabaev, Dulat S.(2016). On one approach to solve the linear boundary value problems for Fredholm integro-differential equations. Journal of Computational and Applied Mathematics, Vol. 294, 342-357. DOI: $10.1016 /$ j.cam.2015.08.023.

7 Dzhumabaev, D.S. (2018). Well-posedness of nonlocal boundary value problem for a system of loaded hyperbolic equations and an algorithm for finding its solution. Journal of Mathematical analysis and Applications, Vol. 461, 1, 817-836. DOI: 10.1016/j.jmaa.2017.12.005.

8 Assanova, A.T. (2018). On a Nonlocal Problem with Integral Conditions for the System of Hyperbolic Equations. Differential equations, Vol. 54, 2, 201-214. DOI: 10.1134/S0012266118020076.

9 Assanova, A.T. (2018). Nonlocal Problem with Integral Conditions for a System of Hyperbolic Equations in Characteristic Rectangle. Russian mathematics, Vol. 61, 5, 7-20. DOI: 10.3103/S1066369X17050024.

10 Orumbayeva, N.T. (2013). Ob odnom alhoritme nakhozhdeniia resheniia periodicheskoi kraevoi zadachi dlia sistemy kvazilineinykh hiperbolicheskikh uravnenii [On an algorithm of finding periodical boundary value problem for system of the quasi-linear of hyperbolic equations]. Sibirskie elektronnye matematicheskie izvestiia - Siberian Electronic Mathematical Reports, Vol. 10, 464-474. DOI: 10.17377/semi.2013.10.036 [in Russian].

11 Orumbayeva, N.T. (2016). On solvability of non-linear semi-periodic boundary-value problem for system of hyperbolic equations. Russian Mathematics (Iz. VUZ). 9, 26-41.

12 Orumbayeva, N., \& Shayakhmetova, B. (2016). On a method of finding a solution of semi-periodic boundary value problem for hyperbolic equations. AIP Conference Proceedings. 1759, 020121. DOI: $10.1063 / 1.4959735$

13 Orumbayeva, N.T. (2016). Algorithms for finding a solution to the initial boundary value problems for differential equations in partial derivatives. Bulletin of the Karaganda University-Mathematics, 2 (82), $107-112$.

14 Orumbayeva, N.T., \& Sabitbekova, G. (2017). A boundary value problem for nonlinear differential equation with arbitrary functions. Bulletin of the Karaganda University-Mathematics, 1 (85), 71-76. DOI: $10.31489 / 2017 \mathrm{M} 1 / 71-76$.

15 Orumbayeva, N.T., \& Sabitbekova, G. (2017). On a Solution of a Nonlinear Semi-periodic Boundary Value Problem for a Differential Equation with Arbitrary Functions. Springer Proceedings in Mathematics and Statistics, Vol. 216, 158-163.

16 Assanova, A.T., Iskakova, N.B., \& Orumbayeva, N.T. (2018). Well-posedness of a periodic boundary value problem for the system of hyperbolic equations with delayed argument. Bulletin of the Karaganda University-Mathematics, 1 (89), 8-14. DOI: 10.31489/2018M1/8-14. 